更に修理補强して $50 \mathrm{~km} / \mathrm{h}$ で衝突させた所脫線して第 288 図の如き破損狀態になる。

顛墔試驗 Immendingen-Singen 線の Hattingen, Talmühle 両驛間で $2: 3$ の急斜面を片側に持つ所に分岐線を 作り、分岐線の先で軌条の片方を持上げ、他方を下に落し、 車体を顛覆陸落させる(第289図)。前回と同じく白線を格子 狀に引き、撮影に便利にする。比較のために 1894 年製の急
行用車䡛を使つた。等落狀態は第 290，291，292，及び 293 図、列行用車輛に対しては第 294 及び295 図の如くなる。そ して軽構造車体の優秀なることを証明してるる。

この実驗結果から色々の有监な結果を得た。これは車体の

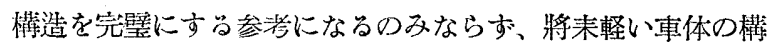
造を探用する上に有力な参考資料となる。（横堀 進）

\title{
12. 船舶及び舶用機関
}

\section{[184] B \& W ニサイクル・クロスヘッド單動新型譏関}

[Motor Ship (E)*, 1939-12, Vol. 20, No. 239, 頁 316 319, 図 1] B \& W 製 $8800 \mathrm{t}, 14 \mathrm{kn}$ 貨物船 “Fernplant”, に B \& W 二サイクルクロスヘッド單動の新型機関が採用さ れた。第296図はその断面を示す。同機はシリンダ 数 9, シリンダ 径 $620 \mathrm{~mm}$, 行程 $1150 \mathrm{~mm}, 122 \mathrm{rev} / \mathrm{mn}, 5500$ I.H であり、シリンダ 径、行程の同じ位末来のランクピス トン 型に比し重量で 8～10\% 重く、雪高さで 15\% 高いに過

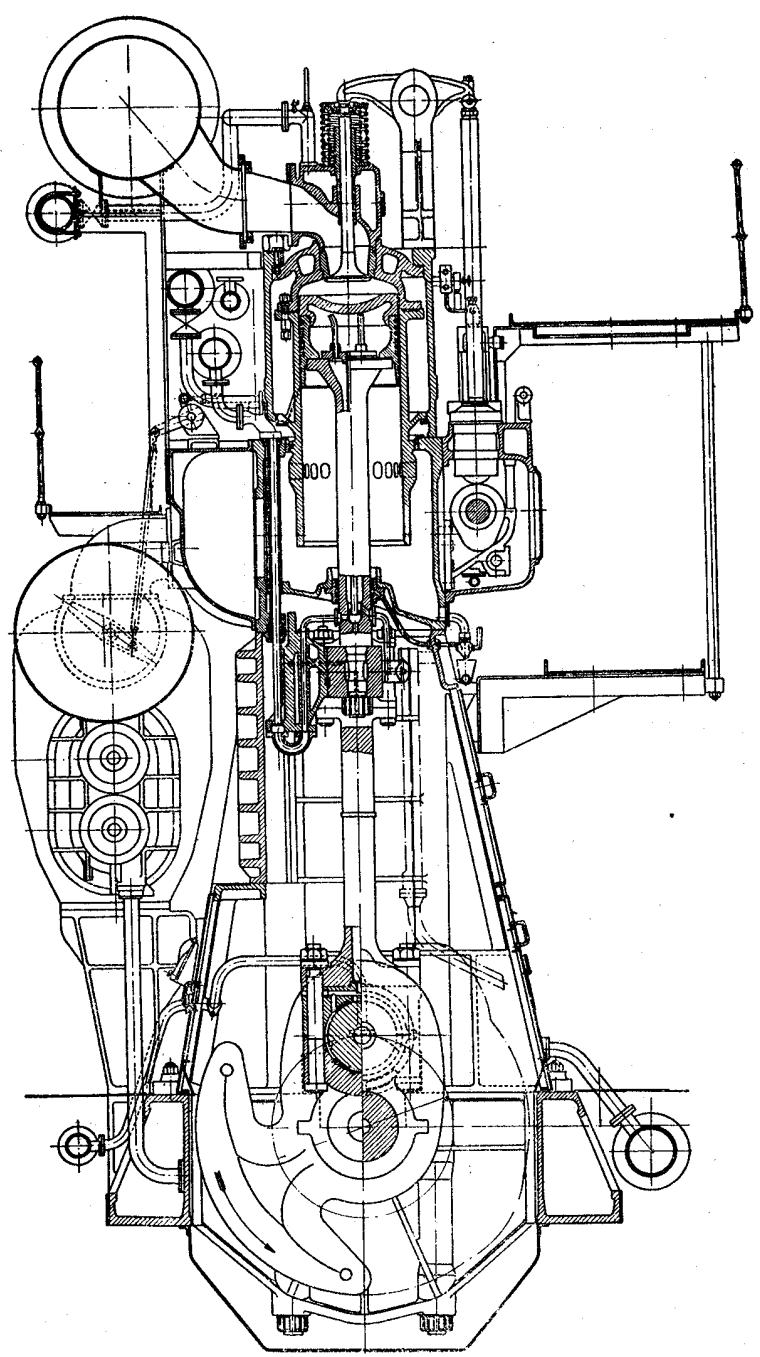

第 296 图 B \& W 二サイクルクロスヘッド啋型機関 昭利 15 年 4 月了
ぎない。

この型には更に大型の シリンダ 径 $740 \mathrm{~mm}$, 行程 1400 $\mathrm{mm}, 115 \mathrm{rev} / \mathrm{mn}, 1$ シリンダ 出力 1000 I.H 或は 850 B.PP のものがある。 (門脇 德一郎)

\section{[185] ヂーゼル船の歯車減速}

[W.D. Lreggest, Motor ship (E)*, 1939-12, Vo1. 20, No. 239, 頁 328 330, 図 3, 袁 1] 海軍では、艦艇のヂーゼ ル 推進に、プロペラ 直結、歯車減速及び電氝推進の三つの 方法を何れも探用してるる。各特長があり、重量及び大きき が制限されす、また運轉の融通性が大して姴求されないとき は、プロペラ 直結が最も簡單、安價で效率がよい。建造費 の高くなることをかまはすに渾轉の融通性、機珹の配置、利 用に重点をおけけば、重量をも考へて、電気推進が最も有利で ある。阙し海軍用には、菌車減速デーゼルが最も安價、䉍 單に、その要求に合つてるる。

菊車装置その物は、菌区、速度等、タービンのプラクティ スがその焦寉用されるが減速比はタービンに比して小さい から、2 段減速の必要はない。多くの場合、歯車の直径は必 要な歯車配置、接手、機関から決り、页、容易に手が屆く 様に決められる。その㭙、崡東の门は直径に対して充分の成 さを持つ椂に、又荞区が許容值になる様に沠められる。これ

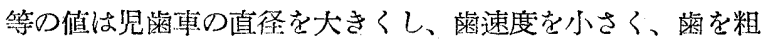
く、文軸受を大きなものにし易い。従て幾何学的に制限され なければ、蒾車は重量軽減のために、仕様による最大限度迄 荷をかけるのが晋通である。又㨝り振動 防止之軸心不一致 を直すために㙨関と児菌車の間に、彈性接手を大れる。する と多筒㙨関の 据り力曲線 は、副振動げけとなるから、歯車 設誈に當つて更に余裕をつける必要はない。

㨝り振動の問題は备車減速の場合でもプロペラ 直結の場 合でも同㥞厄介である。而も機関速度範囲の大きい程、或程 度大きくなり、及クランク靵 の相賞洞さの大きい程、従て より高速度機関の振動系の自然振動数の高い程小さくなる。 ヂーゼル㙨関はその彈性特性を適當にして菊車に直結し 得吕ことは常識である。モーター 船“Milwaukee”はこ の方式による客船の一例であり、1929 年以来渾足な運轉孛 続けてるる。作し、設䚺を变へて主 据り振動を缏用回轉範 囲外にすることが実際㑬に出来ない場合が展ある。それは或 回轉範囲だけ使用を避けるか防止裝置を大れねばならないこ こになる。海軍では凡ゆる型の防止装置を試みたが、結局最 後に有望なものは、振子型のものであり、これが、小型航突 
用㙨関と同㥞に大型ヂーゼル機関にも有效にきけば最も價 值がある。

提り振動の問題は、機関と歯車との間に大れる接手やク ラッチ学決めるときに起る。実際墑船の場合は普通全力で連 轉されるから特殊の型の接手を使へばよいが、海軍用艦艇の 場合は巡航は全力より、遥かに下であ尚から、不要の機関を 切離し得るもので同時に 㨝れに対する彈性接手でなければ ならない。

これを満足さすものは往来数年間流体接手であつたが、最 近 2 年間に スカンヂナビア た ASEA 電气接手を附した船 が 13 隻以上も出未た。これは 捱り振動を傳へす積極的接 手となるものであり、400 rev/mn 以下の低速度機関で、流 体接手を使ふと大きくなるときには、有利である。併し海車 用の大部分は重量と大きさの小さい流体接手である。流体接 手の損失は傳動馬力の 2 3\% であり、艦艇の巡航速度では 電气接手よりもいくらか小さい。その他の点では两者とも大 差ない。
機峨的接手の可能性も決して萧てられたのではなく、今日 ではこれにも多くの満足すべきものがある。併しこれ等は全 体の彈性振動系の自然振動数を下げるものであり、流体或は 電气接手の如く、機関とプロペラ軸 系とを分離するのでは ない。これ等は簡單と效率高い特長を持つてるる。

この外に所謂 エア・フレックス・クラッチ 或は接手なるも のがある。これは接手の一方に自動車のタイヤの如きもの が附いてをり、これが膨んで接手の他方をつかみ、空気压力 によつて ゴム 或は織物を介して回轉を傳へるものである。 こ礼は自動車工業から出来たものであるが、㨝りに対する特 性、実用化は今後の試みに街つものである。

谪船に於ては プロペラ直結デーゼル船 が大多数であるが、 菌事減速のものも次第に增加しつ〉ある。第 37 表はこれを 示してるる。第297 図は米国 Maritime Commission D C2 型船の機関で Nordberg $3000 \mathrm{HP}$ 機関 2 台から成つてるる。

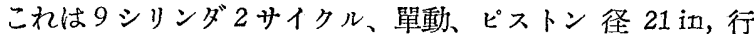
程 $29 \mathrm{in}, 222 \mathrm{rev} / \mathrm{mn}$ で 3158 B. HP である。プロペラ速

\begin{tabular}{|c|c|c|c|c|c|c|c|c|}
\hline 船名 & 船雔 & 噸 数 & $\begin{array}{c}\text { 最高速 } \\
\text { kn }\end{array}$ & プロペラ & $\begin{array}{c}1 \text { 軸の機関数 } \\
\text { 及び型式 }\end{array}$ & 1 輅 B.H & 接 手 型式 & $\begin{array}{l}\text { 可轉数 } \mathrm{rev} / \mathrm{mn} \\
\text { 機関/プロベラ }\end{array}$ \\
\hline $\begin{array}{l}\text { 未分 Rotterdam } \\
\text { Lloyd }\end{array}$ & 客 & $21000 \mathrm{G}$ & 21 & 2 & 4-Sulzer & 13500 & ASEA 電氛 & 一 \\
\hline Robert Ley & 客 & $22000 \mathrm{G}$ & 16 & - & 6-MAN（計) & 12420 (計) & 電气推進 & $235 / 117$ \\
\hline Oslofjord & 貨客 & $18700 \mathrm{G}$ & 19 & 2 & 2-MAN & 8800 & 流体 & $212 / 92$ \\
\hline $\begin{array}{l}\text { 未定 Hamburg- } \\
\text { America Line }\end{array}$ & 貨 & $9500 \mathrm{C}$ & $16^{\frac{1}{2}}$ & - & 3-MAN & 8000 & - & $250 / 125$ \\
\hline $\begin{array}{l}\text { 未定 Netherlands } \\
\text { S. S. Co. }\end{array}$ & 貨 & $11900 \mathrm{C}$ & 16 & 一 & 2-MAN & 8000 & 一 & $215 / 84$ \\
\hline $\left.\begin{array}{l}\text { Goldenfels } \\
\text { Hohenfels } \\
\text { Neidenfels } \\
\text { Tannenfels }\end{array}\right\}$ & 貨 & $11600 \mathrm{C}$ & 16 & 1 & 2-MAN & 7600 & 一 & $210 / 86$ \\
\hline Leipzig & 貨 & $5500 \mathrm{G}$ & - & 1 & 2-MAN & 6000 & Vulcan 流体 & 一 \\
\hline $\begin{array}{l}\text { 未定 U.S. Mari- } \\
\text { time Commission }\end{array}$ & C2貨 & 9300 & $15^{\frac{1}{2}}$ & 1 & 2-Nordberg & 6000 & 流体 & $225 / 92$ \\
\hline Wilhelm Gustloff & 客 & $25500 \mathrm{C}$ & 16 & 2 & 2-MAN & 4800 & - & $220 / 125$ \\
\hline $\left.\begin{array}{l}\text { Anatina } \\
\text { Dogmar Salen } \\
\text { Morviken }\end{array}\right\}$ & 貨 & $9500 \mathrm{C}$ & 14 & 1 & 4-Polar & 4400 & ASEA 電気 & $300 / 90$ \\
\hline Lech & 貨 & $3200 \mathrm{G}$ & - & 1 & 2-Weses-MAN & 3500 & 一 & $230 / 90$ \\
\hline Formosa & 貨 & 13800 & $14 \frac{1}{2}$ & 2 & 2-Polar & 2560 & ASEA 電気 & $300 / 130$ \\
\hline Astrid Thorden & 貨 & $3000 \mathrm{C}$ & 14 & 1 & 2-Polar & $2 c 40$ & ASEA 電氛 & $300 / 130$ \\
\hline $\left.\begin{array}{l}\text { Fidra } \\
\text { Freja }\end{array}\right\}$ & 貨 & $2500 \mathrm{C}$ & 12 & 1 & 2--Polar & 1820 & ASEA 電氛 & $300 / 130$ \\
\hline Roode Zee & 曳船 & 一 & $13 \frac{1}{2}^{\circ}$ & 1 & 2-Smit-MAN & 1800 & Vulcan 流体 & $300 / 115$ \\
\hline $\left.\begin{array}{l}\text { Anita } \\
\text { Astri }\end{array}\right\}$ & 貨 & $3600 \mathrm{C}$ & 12 & 1 & 2-Polar & 1740 & ASEA 電氠 & $298 / 130$ \\
\hline $\begin{array}{l}\text { Sisu. } \\
\text { MMS } 1 .\end{array}$ & $\mid \begin{array}{l}\text { 碎水船 } \\
\text { 掃海:艇 }\end{array}$ & $1600 \mathrm{G}$ & - & 一 & $\begin{array}{l}\text { 1-Polar } \\
\text { Thornycroft }\end{array}$ & $\begin{array}{l}1600 \\
1500\end{array}$ & - & $\begin{array}{c}320 / 160 \\
-\end{array}$ \\
\hline $\begin{array}{l}\text { Imperial } \\
\text { Petrolite }\end{array}$ & 油槽船 & 3140 & $\overline{11}$ & $\overline{1}$ & $\begin{array}{l}\text { 2-Fairbanks- } \\
\text { Morse }\end{array}$ & 1400 & 電気推進 & $400 / 125$ \\
\hline $\begin{array}{l}\text { Waria } \\
\text { Wernia-Wirds } \\
\text { Wirll } \\
\text { Blankenberg } \\
\text { Tarret }\end{array}$ & $\begin{array}{l}\text { 貨 } \\
\text { 曳船 } \\
\text { 試驗 }\end{array}$ & $1300 \mathrm{C}$ & 1.3 & $\begin{array}{l}1 \\
1 \\
2\end{array}$ & $\begin{array}{l}\text { 2-Polar } \\
\text { 2-Bolnes } \\
\text { 1-Paxman } \\
\text { V-type }\end{array}$ & $\begin{array}{l}1400 \\
1200 \\
1000\end{array}$ & ASEA 電兮 & $\begin{array}{c}300 / 130 \\
\ldots \\
1 \cdot 696 / 1 \\
1 \cdot 162 / 1 \\
2 \cdot 38 / 1\end{array}$ 摞後進 \\
\hline
\end{tabular}


度に $92 \mathrm{rev} / \mathrm{mn}$, 歯車損失 $2 \%$, 接手損失 $3 \%$ である。第 299 図はこれと1台の 9 シリンダ、ビストン 径 $21 \mathrm{in}$, 行程 49 in, 2 サイクル、複動 Nordberg B \& W., 同騳力、105 $\mathrm{rev} / \mathrm{mn}$ の機関との比較である。歯車減速デーゼル裴置の
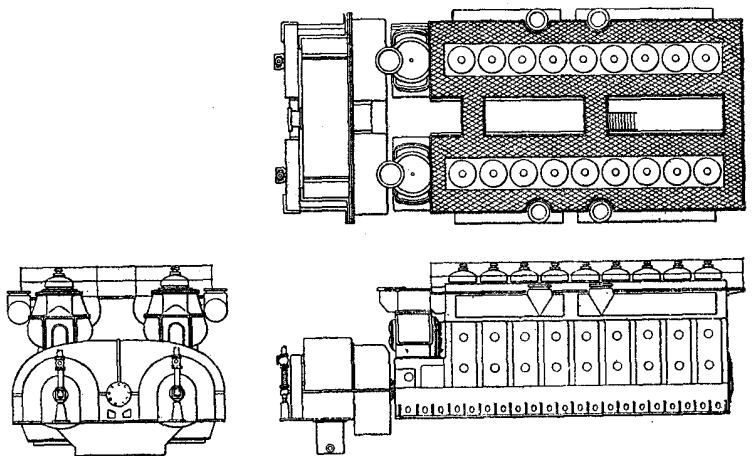

第 297 図 Folk 式減速裝置附 Nordberg 機関

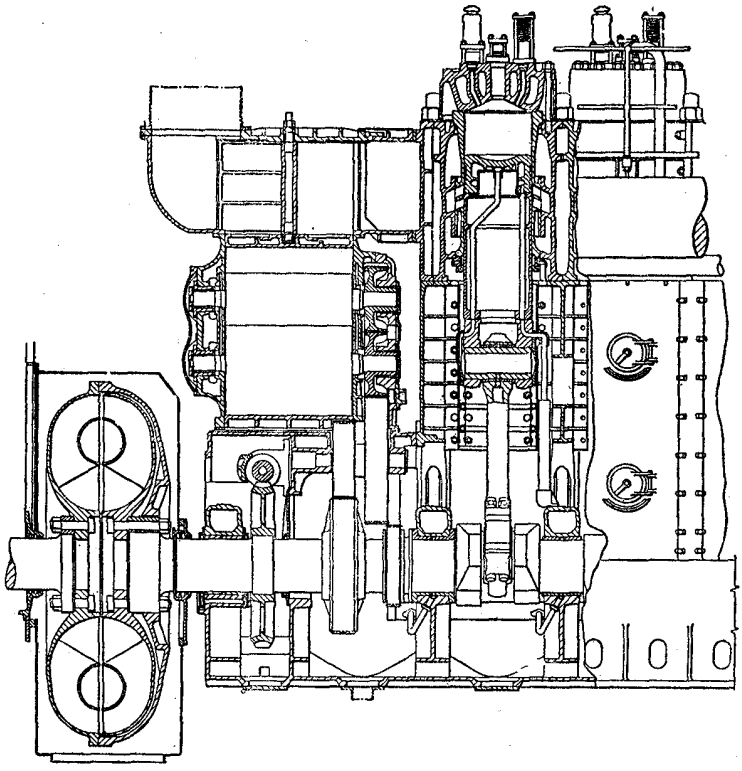

第 298 図 Nordberg 機関用流体接手と 掃除空气揆風機驅動裝置

重量 $412 \mathrm{t}$ に対し後者は $496 \mathrm{t}$ である。第 298 図はその流

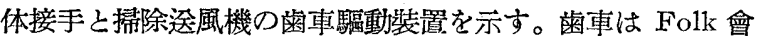
礼製で直結自動飛洙潤滑である。荬車軸受及びその前部にあ る Kingsbury 型推力軸受もこの飛洙方法で潤滑される。流 体接手の被動側の片持重量を釣合すために、児歯車の反対側 には亦み車が附いてるる。

この例に示すものでは、歯車減速の方が軽量、小型で而も 低廉である。彷て將未来大量製產が行はれる様になれば、この
方が盆経済的になるであらう。併し同時に高速度ヂーゼル になるとより上等の燃料が要るとか流体或は電气接手の損失 こいなことが考へられる。これは製油工業の開題であつて今 後に街つべきものであり、製油工業が発達すれば油の種類に
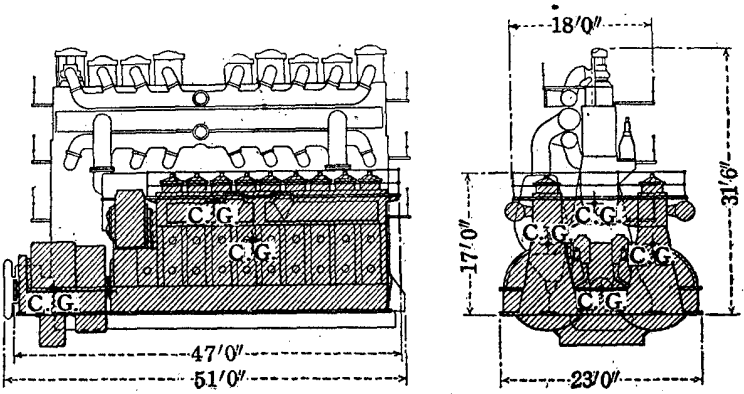

第 299 図 歯車減速機関 と淔結機関の大さ比䡆

よる值段の相遙は問題でなくなっであらう。

結局、歯車減速デーゼル が重量軽減の点に於て他の何れ のヂーゼル 驅動より霓れてをり、それだけ荷物を余計に積 み、武裝を强化し、展範囲の速度で経済的に運轉が出末る。 また㙨関設計者は自由に最も適當な設計が出未るし、船の方 は望みの配置に合致する様な標淮型の機関を採用し得亭。

(門脇 德一郎)

\section{［186］ドイツの潜水艦建造能力}

[Motor Ship (E)*, 1940-1, Vol. 20，No. 240，頁 363] 今次大戰 4 万月䦥の損失は直接、間接何れも潜水艦の魚雷 又は水雷によるものであり、ドイッ注在この潜水艦文びそ の機関製作に全造船能力を傾けてるると思はれる。

ドイッの主なる造船所の船台の数は 75 ，その他に 20 おる から、総計 95 で、1938 年にモーター船 $360000 \mathrm{t}$, 蒸气 船 $140000 \mathrm{t}$ を建造してるる。戰爭開始當時、建造中の商船 52 隻、270000t が 35 の船台を占めてるたと思はれるから、 建造中の他の軍艦を考に大れて、佾 40 の船台は潜水艦建造 に向けられたことになる。すると、同特に 100 隻建造出末 るから $750 \mathrm{t}$ 潜水艦が 9 ケ月で完成するとすれば、月攵 11 隻となる。この数字は次第に增して今年末には月產 20 隻に 達する。1隻 $750 \mathrm{HP}$ として年座 $180000 \mathrm{t}$ である。

潜水艦用デーゼル機関は本均 1 隻 $3000 \mathrm{FP} し て 20$ 隻 で月锖 $60000 \mathrm{HP}$ 必要である。その中 M. A. N. は最大の製 作者であり、昨年內燃機関をこっで $420000 \mathrm{HP}$ 以上製造し てるる所から、月座 $40000 \mathrm{HP}$ は出来る。また Krupp は 月 $10000 \mathrm{H}$, Deutz と D.W. K. で月 $10000 \mathrm{H}$ は 出末来。

(門脇 德一郎)

\section{3. 流体力学及び水力機}

\section{［187］遠心回轉車における超至速流の性質}

[K. W. Sorg, Forschung*, 1939-11, 12, Bd. 10, Nr. 6, 頁 270 285, 図 20] 遠心回轉車の如く機峨的エネルギの
交換を件。气体の流れに於て、流速が音響速度以上になつた 場合に、流路の断面の㥛限質に就て研究したものである。

(山縣 清) 